Edu Consilium: Jurnal BK Pendidikan Islam

Vol 2, No. 1, Februari 2021, hlm. 1 - 11

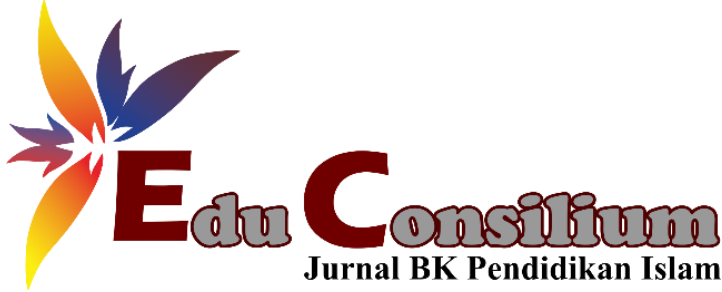

\title{
KONSELING INDIGENOUS: KAJIAN PADA KEPATUHAN MASYARAKAT TERHADAP PROTOKOL KESEHATAN
}

\author{
Moh. Ziyadul Haq Annajih ${ }^{1 *}$, Diana Vidya Fakhriyani ${ }^{2}$, Ishlakhatus Sa'idah ${ }^{3 .}$ \\ ${ }^{1}$ Bimbingan Penyuluhan Islam, STAI Miftahul Ulum Pamekasan \\ ${ }^{2}$ Bimbingan dan Konseling Pendidikan Islam, Fakultas Tarbiyah, IAIN Madura \\ ${ }^{3}$ Bimbingan dan Konseling Pendidikan Islam, Fakultas Tarbiyah, IAIN Madura \\ *e-mail: najihas@gmail.com
}

\begin{tabular}{ll}
\hline \hline & Abstract \\
\hline Keywords: & One year after the pandemic hit this nation, all efforts have been made by the government \\
Counselling; & to break the chain of spreading this virus, such as the imposition of PSBB (large-scale \\
Indigenous; & social restrictions) in certain areas. However, these efforts to date have not been able to \\
Covid-19. & produce sweet results. The problem is that most people are ignorant and neglect to pay \\
& attention to and comply with health protocols, such as wearing masks, maintaining \\
& distance, and washing hands. Therefore, we need an alternative solution to solving these \\
& problems, namely through the local cultural approach (indigenous). Indigenous \\
& counseling is believed to be able to construct people's views to view the realities and \\
& problems of life based on their beliefs and culture so that they can make people aware of \\
& compliance with health protocols and the dangers of Covid-19.
\end{tabular}

\begin{tabular}{ll}
\hline \hline & Abstrak: \\
\hline Kata Kunci: & Satu tahun berlalu Pandemi melanda bangsa ini, ini segala upaya telah dilakukan oleh \\
Konseling; & pemerintah untuk memutus mata rantai penyebaran virus ini, seperti pemberlakuan PSBB \\
Indigenous; & (pembatasan sosial berskala besar) pada daerah-daerah tertentu. Namun, upaya-upaya \\
Covid-19. & tersebut sampai saat ini belum mampu membuahkan hasil manis. Permasalahannya adalah \\
& sebagian besar masyarakat acuh dan lalai memperhatikan dan mematuhi protokol \\
& kesehatan, seperti menggunakan masker, menjaga jarak, dan mencuci tangan. Karenanya, \\
& diperlukan sebuah solusi alternatif pemecahan permasalahan tersebut, yaitu melalui \\
& pendekatan budaya lokal (indigenous). Konseling indigenous diyakini dapat \\
& mengkonstruk pandangan masyarakat untuk memandang realitas dan permasalahan \\
& kehidupan berdasarkan keyakinan dan budayanya sehingga mampu menyadarkan \\
& masyarakat untuk mematuhi protokol kesehatan dan bahaya Covid-19.
\end{tabular}

OEdu Consilium: Jurnal BK Pendidikan Islam

Bimbingan dan Konseling Pendidikan Islam

Institut Agama Islam Negeri Madura, Indonesia

\section{PENDAHULUAN}

Satu tahun berlalu Pandemi melanda bangsa ini, tepatnya pada awal tahun 2020 Corona virus jenis baru (SARS-CoV-2) atau disebut juga Corona Virus Disease (Covid-19) yang berasal dari Wuhan, Tiongkok ini masuk ke Indonesia. Pemerintah Indonesia berdasarkan Keputusan Presiden (Keppres) Nomor 11 Tahun 2020 tentang Penetapan 
Kedaruratan Kesehatan Masyarakat Corona Virus Disease 2019 (Covid-19) telah menyatakan bahwa dengan adanya Covid-19 ini wajib dilakukan upaya penanggulangan sebagai kedaruratan kesehatan masyarakat (Tuwu, 2020). Sampai saat ini segala upaya telah dilakukan oleh pemerintah untuk memutus mata rantai penyebaran virus ini, seperti pemberlakuan WFH (work from home), SFH (study from home), bahkan pemberlakuan PSBB (pembatasan sosial berskala besar) pada daerah-daerah tertentu yang telah termaktub dalam Peraturan Pemerintah Nomor 21 Tahun 2020 pada Maret 2020.

Kebijakan yang telah dilakukan pemerintah tersebut sampai saat ini belum mampu membuahkan hasil manis. Penyebaran Covid-19 semakin hari bukan justru melandai, tetapi semakin meningkat dan bertambah drastis. Salah satu penyebab tingginya penularan tersebut adalah kepatuhan masyarakat terhadap kebijakan pemerintah tersebut, salah satunya yaitu selalu memperhatikan protokol kesehatan dalam menjalani segala aktivitasnya (Wiranti, dkk, 2020). Selain pembatasan sosial, sebagaimana himbauan WHO (World Health Organization) salah satu usaha memutus mata rantai penyebaran virus ini adalah rajin membersihkan tangan menggunakan sabun atau cairan berbasis alkohol, dan selalu menggunakan masker, sehingga pemerintah mengemasnya dengan jargon 3M, yaitu memakai masker, menjaga jarak, dan mencuci tangan.

Implementasi protokol kesehatan dengan 3M-nya tidak akan membuahkan hasil yang optimal tanpa partisipasi masyarakat, sehingga diperlukan upaya untuk meningkatkan kepatuhan masyarakat dalam mensukseskan implementasi protokol kesehatan tersebut. Sejauh ini pemerintah kerap melakukan razia terhadap pelanggar protokol kesehatan di sejumlah daerah. Namun masih banyak ditemui masyarakat yang tidak mematuhinya. Hal itu disebabkan oleh anggapan masyarakat yang tidak mempercayai bahaya dan adanya Covid-19, tidak hanya itu sebagian masyarakat berkeyakinan penyakit (Covid-19) itu berasal dari Tuhan dan seandainya sakit bahkan meninggal itu adalah kehendak Tuhan. Di sisi lain, anggapananggapan masyarakat tersebut tidak lepas dari upaya penanganan pemerintah sejak awal masuknya virus ini ke Indonesia. Pemerintah nampak kurang mempersiapkan diri untuk mengedukasi masyarakat. Elite pemerintah melalui pernyataan-pernyataannya di media tidak berusaha memberi pemahaman yang baik kepada masyarakat, bahkan seakan menganggap Covid-19 tidak membahayakan (Arditama \& Lestari, 2020).

Kepatuhan menjadi permasalahan yang sangat mendasar di masa pandemi Covid-19 ini. Artinya, kepatuhan menjadi kunci keberhasilan implementasi protokol kesehatan tersebut. Penelitian Harlianty (2020) menyatakan bahwa kepatuhan berkaitan dengan kesadaran 
(awareness) terhadap bahaya Covid-19. Dalam hal ini, perilaku patuh dapat merepresentasikan bahwa masyarakat telah memahami dampak dari Covid-19. Perilaku masyarakat untuk patuh dipengaruhi oleh beberapa faktor. Faktor-faktor tersebut mencakup otoritas atau figur yang memiliki peran atau pengaruh, kelangkaan, validasi sosial, perilaku timbal balik (reciprocation), konsistensi dan komitmen perilaku (Cialdini, R. B., \& Goldstein, 2004). Penelitian yang berkaitan dengan kepatuhan di masa pandemi Covid-19 ini adalah kepatuhan didorong oleh kondisi ekonomi, motivasi intrinsik seperti ketika individu merasa mampu untuk patuh (Driscoll, J., 2020). Selain itu, teradapat juga beberapa indikasi bahwa alas an ekstrinsik perilaku patuh adalah adanya kemungkinan hukuman dan penegakan keadilan (Folmer, C. R., 2020).

Salah satu upaya meningkatkan kepatuhan masyarakat terhadap protokol kesehatan dari bimbingan konseling adalah melalui pengembangan konseling dengan pendekatan budaya lokal (indigenous) (Suci Prasasti, 2020). Konseling indigenous dapat dijadikan sebagai alternatif solusi dalam mengatasi permasalahan yang berkaitan dengan protokol kesehatan di masa pandemi Covid-19 ini karena konseling indigenous dapat membentuk pola pikir masyarakat terhadap manusia dan lingkungannya. Selain itu, konseling indigenous juga memiliki pandangan terhadap manusia, kepribadian manusia, tujuan hidup, dan nilai-nilai sebagai prinsip dalam kehidupannya (Arifin, 2013). Dalam perspektif konseling multibudaya, keberhasilan konseling adalah ketika konselor mampu berkomunikasi secara efektif dengan memahami latar budaya konseli (Putri, 2016). Oleh karena itu, pendekatan yang berdasarkan pada budaya menjadi lebih efektif karena konseli akan lebih merasa diterima.

Konseling indigenous di dalamnya berisikan pemikiran, budaya, dan keyakinankeyakinan dalam kehidupan masyarakat tradisional secara objektif maupun subjektif. Pandangan subjektif berisikan tentang keunikan masyarakat secara individu dan pandangan objektif berisikan tentang struktur budaya masyarakat berasal (Rangka, 2016). Konseling indigenous hadir sebagai sebuah pendekatan yang berdasar pada pemikiran, budaya, dan nilai-nilai (belief) masyarakat tersebut sehingga diharapkan mampu menarik partisipasi masyarakat untuk mematuhi protokol kesehatan sebagai upaya pencegahan Covid-19.

\section{METODE}

Penelitian menggunakan metode atau pendekatan penelitian kualitiatif dengan tipe kepustakaan (library research). Kepustakaan atau studi pustaka dapat dimaknai sebagai suatu rangkaian kegiatan yang berkaitan dengan pengumpulan data pustaka. Studi pustaka juga 
berkaitan dengan kajian-kajian teoritis berdasarkan referensi literatur-literatur ilmiah (Sugiyono, 2012). Sumber-sumber yang digunakan dalam penelitian ini antara lain bukubuku teks, jurnal ilmiah, dan literatur-literatur yang relevan dengan topik penelitian.

Metode penelitian keputakaan ini digunakan untuk menyusun serta mendeskripsikan menganai konseling indigenous sebagai alternatif pemecahan permasalahan di masa Pandemi Covid-19. Penelitian ini dilakukan melalui beberapa tahapan sebagai berikut (Purwoko, 2021);

1. Menentukan topik permasalahan;

2. Mengeksplorasi informasi yang sesuai dengan topik;

3. Menentukan fokus kajian penelitian;

4. Mengumpulkan sumber data yang dibutuhkan;

5. Mempersiapkan penyajian data;

6. Menyusun laporan

Dalam penelitian kepustakaan ini menggunakan teknik pengumpulan data dengan metode dokumentasi. Metode dokumentasi adalah suatu metode yang digunakan untuk memperoleh data mengenai suatu hal atau variable berupa buku, jurnal, dan literatur-literatur yang relevan (Arikunto, 2010).

\section{HASIL}

Pandemi ini tidak hanya mengancam kesehatan masyarakat, namun juga menghantam segala aspek kehidupan masyarakat, baik permasalahan ekonomi, politik, sosial, budaya, bahkan pendidikan. Pusat ekonomi dibatasi dan pembelajaran di sekolah dari tingkat dasar sampai perguruan tinggi dilakukan secara daring. Hal yang paling mengejutkan adalah semakin banyaknya korban berjatuhan akibat pandemi Covid-19 ini. Tanpa disadari, dampak pandemi Covid-19 telah mengubah tatanan kehidupan masyarakat sampai keseluruh sendisendi kehidupan secara drastis.

Semakin hari, kasus pasien terpapar Covid-19 semakin meningkat. Hal itu disebabkan oleh kurangnya kesadaran dan kepatuhan masyarakat. Di sisi lain, penanganan dan kesigapan menghadapi pandemi yang sangat terbatas dan ketidakpatuhan masyarakat terhadap permberlakuan aturan menjadi salah satu pemicu. Kepatuhan masyarakat di masa pandemi Covid-19 terhadap protokol kesehatan yang telah ditetapkan pemerintah sejak awal masa pandemi dapat luntur begitu saja oleh beberapa hal, misalnya penanganan pemerintah sejak awal masuknya virus ini ke Indonesia. Pemerintah nampak kurang mempersiapkan diri untuk 
mengedukasi masyarakat. Elite pemerintah melalui pernyataan-pernyataannya di media tidak berusaha memberi pemahaman yang baik kepada masyarakat, bahkan seakan menganggap Covid-19 tidak membahayakan.

Terlepas dari semua itu, dalam menghadapi pandemi Covid-19 diperlukan keseriusan pemerintah sekaligus kepatuhan masyarakat. Pemerintah menghimbau untuk membantu upaya pemerintah memutus mata rantai penyebaran Covid-19 dengan menerapkan protokol kesehatan. Kemudian, masyarakat hendaknya patuh terhadap himbauan tersebut. Sebagaimana penelitian yang dilakukan oleh Fatimah, dkk (2021) bahwa kepatuhan masyarakat terhadap protokol kesehatan dipengaruhi oleh beberapa faktor, yaitu kesadaran diri, percaya pada pemerintah, dan persepsi ancaman.

Pertama, kesadaran diri. Kesadaran masyarakat terahadap bahaya Covid-19 mampu mewujudkan kepatuhan masyarakat dalam menerapkan protokol kesehatan (Harlianty, 2020). Kesadaran diri dalam konteks ini mencakup himbauan pemerintah yaitu penerapan protokol kesehatan. Dalam hal ini, masyarakat menerapkan himbauan pemerintah dalam menjalankan aktivitas sehari-hari sebagaimana yang telah ditetapkan seperti menjaga jarak, memakai masker, dan mencuci tangan. Kedua, percaya pada pemerintah. Pemerintah merupakan figure otoritas (authority) yang memiliki peran atau pengaruh bagi individu atau kelompok. Hal ini selaras dengan paparan Cialdini (2004) bahwa kepercayaan terhadap pemerintah memberikan kontribusi (meskipun sangat kecil) terhadap perilaku kepatuhan selama masa pandemi Covid19. Ketiga, persepsi ancaman. Persepsi ancaman merupakan keadaan individu mempersepsikan sebuah situasi negatif yang membuat mereka membutuhkan perlindungan (Arqi, M., Chusniyah, T., \& Priyambodo, 2016). Dengan adanya kemungkinan ancaman menjadi faktor masyarakat bertindak patuh. Oleh karena itu, adanya risiko tertular Covid-19 menjadi alasan individu bertindak patuh.

Pada akhirnya, pemerintah akan memasrahkan masalah penanganan Covid-19 ini kepada masyarakat sepenuhnya. Jika masyarakat tidak mematuhi dan mengabaikan protokol kesehatan, maka masyarakat akan menanggung sendiri akibatnya. Karenanya, pemerintah beberapa bulan yang lalu mengajak masyarakat untuk "berusaha hidup damai” dengan Covid19. Dalam hal ini, pemerintah sebenarnya sedang memilih kebijakan herd immunity dalam masyarakat. Herd immunity adalah kekebalan atau daya tahan tubuh di masyarakat sehingga secara tidak langsung akan menghentikan mata rantai penyebaran Covid-19 (Suci Prasasti, 2020). Walaupun pada bagian tertentu pemerintah seakan ragu-ragu dengan kebijakan ini karena berisiko tinggi, yaitu semakin banyak lagi korban berjatuhan akibat Covid-19 ini. 


\section{Konseling Indigenous}

Indonesia merupakan bangsa yang memiliki keragaman budaya. Keragaman budaya ini adalah kekayaan yang diperoleh dari warisan turun temurun yang harus dilestarikan. Budaya adalah warisan yang sangat berharga apabila tidak ada dilestarikan akan hilang, bahkan diambil oleh bangsa lain. Perkembangan teknologi yang sangat pesat, serta masuknya budaya luar dan pengaruh globalisasi menjadi ancaman dan tantangan bagi budaya (lokal) dan nilai-nilai tradisional. Budaya lokal yang memiliki nilai-nilai tradisional terhadap keberadaan suatu masyarakat masih bisa diterima dan dikembangkan menjadi nilai yang sangat berharga, seperti bahasa daerah, kesenian, adat istiadat, pengetahuan lokal, dan sebagainya. Nilai-nilai tersebut kemudian dijadikan sebagai pijakan manusia dalam kehidupan masyarakat yang khas (Berger P.L. \& Thomas Luckmann, 1991).

Nilai-nilai kearifan lokal (local indigenous) dalam suatu budaya merupakan harta warisan turun temurun. Nilai-nilai tersebut kemudian menjadi sebuah karakteristik bangsa ini yang memiliki keluhuran dan keagungan sebagai suatu bangsa yang beradab. Namun, budaya saat ini mengalami pergeseran sosial dampak dari globalisasi yang telah memengaruhi sendisendi kehidupan bangsa ini. Banyak fenomena-fenomena yang terjadi, seperti kekerasan, anarkisme, kesusilaan, kriminalitas, dan kejahatan. Fenomena tersebut mencoreng karakter bangsa ini yang identik dengan kesopanan, kesantunan, dan menjunjung tinggi harkat dan martabat manusia.

Kearifan lokal adalah keseluruhan pengalaman, di dalamnya terdapat gagasan, pandangan hidup, nilai, norma, bahasa maupun adat istiadat yang melekat pada suatu masyarakat -yang dianggap baik- dan digunakan secara turun temurun (Moordiningsih, 2009; Grayshield., et., 2010). Nilai-nilai kearifan lokal berarti dapat dijadikam sebagai pemecahan permasalahan dalam menghadapi pergesaran sosial dampak dari derasnya arus globalisasi karena di dalam nilai-nilai kearifan lokal tesebut terdapat nilai-nilai luhur yang telah turun temurun melekat sebagai karakter bangsa hingga saat ini.

Disinilah yang dijadikan pijakan utama dalam konseling indigenous, yaitu proses internalisasi budaya lokal dalam proses konseling. Budaya merupakan kekhasan individu dalam berperilaku dan bersosial. Konseling indigenous merupakan proses bantuan kepada individu untuk menyelesaikan permasalahan dalam kehidupan sosial dan kemasyarakatan yang berdasar pada prinsip-prinsip, keyakinan, cara berpikir, dan pengetahuan lokal tempat individu tinggal dan/atau berasal (Sue, D. W.,\& Sue, 2008). Konseling indigenous berkaitan erat dengan budaya yang melekat pada masyarakat. Dalam pelaksanaannya, konseling 
indigenous berpijak pada praktik nilai-nilai budaya masyarakat melalui internalisasi pengetahuan sampai dengan pola perilaku (Ha Chong, F. H., \& Hung-Yi, 2002).

Dalam praktiknya, konseling indigenous menuntut konselor untuk belajar dan memiliki wawasan terkait model "penyembuhan" yang berasal dari konseli berasal. Konselor disini memfungsikan dirinya sebagai fasilitator untuk menfasilitasi dukungan sistem dalam rangka penyembuhan konseli tersebut berasal (Sue, D. W.,\& Sue, 2008). Artinya, konselor terlibat secara langsung untuk membantu konseli berdasarkan nilai-nilai, keyakinan, dan budaya konselinya sehingga mampu mencapai tujuan konseling yang lebih cepat.

\section{PEMBAHASAN}

Manusia tidak bisa lepas dari budaya. Budaya adalah proses tumbuh kembangnya manusia hidup dalam suatu kelompok yang memiliki nilai dan norma yang kemudian disebut dengan masyarakat. Nilai dan norma yang berkembang di masyarakat menjadi prinsip dalam kehidupannya. Setiap budaya masyarakat memiliki karakteristik masing-masing yang berbeda-beda karena budaya adalah hasil dari proses berpikir dan karya suatu masyarakat. Budaya memiliki nilai-nilai yang agung dan tidak bisa dilepaskan dari masyarakat. Oleh karena itu, budaya dapat digunakan sebagai salah satu cara untuk mengenal dan memahami masyarakat tertentu.

Di masa pandemi Covid-19 ini, untuk memberikan pemahaman dan pengetahuan kepada masyarakat tidak hanya mengandalkan tenaga medis, bahkan petugas keamaan sebagai penegak kedisiplinan protokol kesehatan. Penyebaran Covid-19 tidak bisa hanya dilihat dari kacamata kesehatan saja, tetapi sosial budaya menjadi sisi yang perlu untuk diperhatikan. Misalnya, cara pandang masyarakat terhadap Covid-19 ini, pandangan masyarakat yang tidak mempercayai bahaya dan adanya Covid-19, masyarakat berkeyakinan penyakit (Covid-19) itu berasal dari Tuhan dan seandainya sakit bahkan meninggal itu adalah kehendak Tuhan. Berdasar pada pandangan masyarakat tersebut yang kemudian membentuk sikap dan perilaku yang acuh, bahkan menganggap tidak perlu mengikuti protokol kesehatan seperti menggunakan masker, menjaga jarak, dan mencuci tangan.

Berdasarkan permasalah di atas, penanganan Covid-19 perlu dilakukan dengan menggunakan pendekatan sosial budaya. Penanganan Covid-19 tidak dapat dilakukan dengan hanya melibatkan unsur medis saja. Hal itu dikarenakan keduanya saling berkaitan, sehingga penting memperhatikan unsur-unsur sosial budaya dalam pananganan permasalahan di masa pandemi Covid-19. Dinamika yang terjadi dewasa ini tidak bisa menyelesaikan permasalahan 
tersebut dengan hanya mengandalkan kecanggihan tekhnologi karena masyarakat Indonesia sangat beragam (diversity) dengan tingkat pengetahuan dan budaya yang berbeda. Sebagian kelompok tertentu, pemanfaatan media sosial cukup efektif mensosialisasikan protokol kesehatan. Namun, sebagian besar kelompok masyarakat Indonesia tidak cukup hanya dengan memanfaatkan media sosial saja. Peranan budaya lokal sangat penting dalam membantu mensosialisasikan anjuran mematuhi protokol kesehatan selama masa pandemi Covid-19 ini. Sebagian masyarakat tersebut lebih meyakini tradisi, adat istiadat, dan nilainilai yang melekatnya daripada informasi-informasi yang diperoleh media sosial. Apalagi dewasa ini, media sosial banyak berisi berita-berita bohong (hoax) yang menyesatkan, bahkan dapat menimbulkan permasalahan baru.

Penerapan protokol kesehatan -yang disebut 3M- yaitu menggunakan masker, mencuci tangan, dan menjaga jarak (social disntancing) sebagai upaya memutus mata rantai penyebaran Covid-19. Namun, dalam implementasinya, protokol kesehatan yang ditetapkan pemerintah menimbulkan kebingungan di masyarakat. Banyak masyarakat yang tidak mematuhi protokol kesehatan karena belum mampu memberikan pemahaman dan pengetahuan masyarakat bawah (Arditama \& Lestari, 2020). Misalnya, dalam implementasi menjaga jarak (social distancing) dianggap sebagai bentuk perilaku yang anti sosial dan melanggar tatanan kehidupan sosial yang tidak sesuai dengan nilai-nilai dan norma-norma yang berlaku. Tidak hanya itu, misalnya juga himbauan untuk bekerja dari rumah (work from home) yang dianggap sebagai ancaman ekonomi masyarakat. Pedagang tidak bisa menggelar lapaknya di pasar-pasar, sopir tidak bisa mendapatkan penumpang, dan sebagainya. Himbauan-himbauan itulah yang menjadi ancaman dan kekhawatiran masyarakat. Sedangkan kekhawatiran yang sebenarnya adalah ketika keadaan (pandemi) ini berlangsung terus menerus tanpa tahu kapan akan berakhir.

Untuk memahami kondisi masyarakat diperlukan upaya untuk menemukan apa yang menjadi keinginan, pemikiran, dan sosial budaya yang membentuknya. Jika tidak memahami kondisi masyarakat tersebut dikhawatirkan menjadi permasalahan yang akan semakin memperparah tatanan kehidupan masyarakat, bahkan menjadi konflik psikik dan fisik pada masyarakat, karena pandemi ini telah berdampak pada hancurnya sendi-sendi kehidupan masyarakat, seperti terjadinya PHK dimana-mana, pengangguran, kriminalitas akibat masalah ekonomi yang tidak berkesudahan.

Konseling indigenous merupakan upaya bantuan yang diberikan kepada individu dalam menghadapi realitas dan permasalahan dalam kehidupan masyarakat dengan 
menggunakan pendekatan budaya tempat individu berasal. Nilai-nilai kearifan lokal merupakan warisan budaya leluhur dianggap sebagai tatanan yang memiliki fungsi dan tujuan tertentu bagi masyarakat (Sarmadan, 2013). Sebagai upaya pemecahan permasalahan di masa pandemi Covid-19, pemerintah dapat melakukan upaya-upaya memutus mata rantai covid-19 melalui pendekatan konseling indigenous yang berdasar pada nilai-nilai lokalitas yang dapat dituangkan dalam kebijakan-kebijakannya.

Pertama, melakukan sosialisasi untuk mematuhi protokol kesehatan dengan menyisipkan materi-materi sosialisasi tersebut dengan seni tradisi berbasis budaya lokal. Misalnya, menggunakan cerita rakyat, lagu daerah, atau wayang sehingga masyarakat lebih mudah memhami dan menerima untuk turut berpartipasi melaksanakan anjuran tersebut. Dengan menyentuh budaya lokal, masyarakat diharapkan mengindahkan anjuran dan himbauan untuk mematuhi protokol kesehatan tanpa perlu menggunakan paksaan atau sanksi. Kedua, melibatkan tokoh masyarakat, kepala adat, atau pimpinan adat dalam mensosialisasikan pentingnya mematuhi protokol kesehatan. Keterlibatan tokoh sentral akan lebih efektif dan mampu menyentuh masyarakat secara langsung. Di sisi lain, pemerintah dapat upaya untuk menggerakkan seluruh elemen pemerintahan sampai tingkat terendah (RT) untuk turut aktif mensosialisasikan pentingnya mematuhi protokol kesehatan.

Pandemi Covid-19 akan hilang atau sebaliknya. Semuanya itu tergantung tingkat kesadaran dan kepatuhan masyarakat dalam mematuhi protokol kesehatan. Di sinilah konseling indigenous dapat dijadikan sebagai alternatif pemecahan permasalahan di masa pandemi melalui pendekatan budaya lokal. Dalam proses konseling, konselor menggunakan budaya lokal sebagai solusi menjawab ketakutan dan kekhawatiran masyarakat. Pandemi Covid-19 adalah sebuah realitas yang harus dihadapi dan segala risiko akibatnya untuk dihindari dengan memberikan pemahaman dan pengetahuan yang benar.

Masyarakat meyakini pandemi Covid-19 ini merupakan bencana yang sebagai bentuk teguran dari Tuhan kepada manusia. Pamahaman tersebut adalah pemahaman budaya yang positif sehingga masyarakat berisakp lebih waspada di masa pandemi Covid-19 ini. Budaya lokal inilah yang akan menjadi fasilitator pemerintah untuk mensosialisasikan pentingnya mematuhi protokol kesehatan supaya pandemi Covid-19 ini segera berlalu. Budaya lokal memandang pandemi Covid-19 sebagai alur alam semesta bahwa setiap kejadian dan peristiwa memiliki makna dan hikmah dibaliknya.

Pandemi Covid-19 dapat dimaknai positif sebagai peristiwa yang membuat manusia untuk lebih sadar dan peduli terhadap lingkungan sekitarnya. Hubungan antara manusia dan 
hubungan manusia dengan bumi. Disisi lain, peristiwa pandemi Covid-19 membuat bumi menjadi lebih bersih karena sementara waktu terbebas dengan polusi. Manusia pun mulai menyadari bahwa siapa pun bisa terpapar Covid-19 sehingga lebih peduli antar sesama. Covid-19 bukan penyakit biasa, penyakit ini telah memakan banyak korban selama setahun terakhir ini, bahkan banyak tenaga medis menjadi korban akibat menangani pasien Covid-19. Dengan demikian, manusia selalu beupaya untuk lebih tenang dan selalu berhati-hati di masa pandemi Covid-19 ini.

\section{SIMPULAN}

Pandemi Covid-19 akan hilang atau sebaliknya. Semuanya itu tergantung tingkat kesadaran dan kepatuhan masyarakat dalam mematuhi protokol kesehatan. Penanganan Covid-19 tidak dapat dilakukan dengan hanya melibatkan unsur medis saja. Hal itu dikarenakan keduanya saling berkaitan, sehingga penting memperhatikan unsur-unsur budaya dalam pananganan permasalahan di masa pandemi Covid-19. Masyarakat Indonesia yang selalu berpegang teguh pada nilai-nilai budaya menjadi dasar penting dalam menemukan pemecahan permasalahan di masa pandemi Covid-19 ini. Nilai-nilai budaya mengandung maksud dan tujuan terbentuknya masyarakat yang beradab.

Konseling indigenous merupakan upaya bantuan yang diberikan kepada individu dalam menghadapi realitas dan permasalahan dalam kehidupan masyarakat dengan menggunakan pendekatan budaya tempat individu berasal. Konseling indigenous sangat berkaitan dengan budaya di masyarakat. Dalam pelaksanaannya, konseling indigenous berpijak pada praktik nilai-nilai budaya masyarakat yang berupaya untuk menginternalisasi pengetahuan sampai dengan pola perilaku. Konseling indigenous menuntut konselor untuk belajar dan memiliki wawasan terkait model "penyembuhan" yang berasal dari konseli berasal.

\section{DAFTAR RUJUKAN}

Arditama, E., \& Lestari, P. (2020). Jogo Tonggo : Membangkitkan Kesadaran Dan Ketaatan Warga Berbasis Kearifan Lokal Pada Masa Pandemi Covid-19 Di Jawa Tengah. Jurnal Pendidikan Undiksha, 8(2), 157-167.

Arifin, S. (2013). Konseling Indegenous Berbasis Pesantren: Teknik Pengubahan Tingkah Laku Kalangan Pesantren. 1, 7(1), 93-115.

Arikunto, S. (2010). Prosedur Penelitian Suatu Pendekatan Praktik. Jakarta: Rineka Cipta.

Arqi, M., Chusniyah, T., \& Priyambodo, A. B. (2016). Persepsi Ancaman sebagai Prediktor Intoleransi Politik Terhadap Jamaah Ahmadiyah pada Jamaah Nahdlatul Wathan Pancor Lombok Timur. Universitas Negeri Malang. 
Berger P.L. \& Thomas Luckmann, L. (1991). The social construction of reality: a treatise in the sociology of knowledg.

Cialdini, R. B., \& Goldstein, N. J. (2004). Social influence: Compliance and conformity.

Driscoll, J., Sonin, K., Wilson, J., \& Wright, A. L. (2020). Poverty and Economic Dislocation Reduce Compliance with COVID-19 Shelter-in-Place Protocols.

Fathimah, A. F., Al-islami, M. F., Gustriani, T., Rahmi, H. A., Gunawan, I., Agung, I. M., ... Kasim, S. (2021). Kepatuhan Masyarakat Terhadap Pemerintah Selama Pandemi: Studi Eksplorasi Dengan Pendekatan Psikologi Indigenous. 2(1), 15-22.

Folmer, C. R., Kuiper, M. E., Olthuis, E., Kooistra, E. B., de Bruijn, A. L. (2020). Sustaining Compliance with Covid-19 Mitigation Measures? Understanding distancing behavior in the Netherlands during June 2020.

Ha Chong, F. H., \& Hung-Yi, L. (2002). Indigenous Counseling in the Chinese Cultural Context:Experience Transformed Model. Asian Journal of Counselling.

Harlianty, R. A., Widyastuti, T., Mukhlis, H., \& Susanti, S. (2020). Study on Awareness of Covid-19, Anxiety and Compliance on Social Distancing in Indonesia During Coronavirus Disease 2019 (COVID-19) Pandemic.

Moordiningsih, 2009; Grayshield., et., al. (2010). Optimisme MengkristalkanKearifan Lokal. In A. Supratikna \& Tjipto Susana (Eds), Redefinisi Psikologi Indonesia dalam Keberagaman. Jakarta: HIMPSI.

Purwoko, D. A. B. (2021). Studi Kepustakaan Penerapan Konseling Realita Terhadap Penerimaan Diri Peserta Didik. Konseling, Bimbingan Pendidikan, Fakultas Ilmu Surabaya, Universitas Negeri Konseling, Bimbingan Pendidikan, Fakultas Ilmu Surabaya, Universitas Negeri, 31-41.

Putri, A. (2016). Pentingnya kualitas pribadi konselor dalam konseling untuk membangun hubungan antar konselor dan konseli. Jurnal Bimbingan Konseling Indonesia, 1, 1013.

Rangka, I. B. (2016). Konseling Indigenous: Rekonstruksi Konseling di Tengah Keragaman Budaya. Optimalisasi Peran Konselor Melalui Pemanfaatan Berbagai Pendekatan Dan Terapi Dalam Pelayanan Konseling, 19-20.

Sarmadan. (2013). Upacara Adat Katoba pada Masyarakat Muna: Analisis Struktural, NilaiNilai Kultural, dan Pemanfaatannya dalam Pembelajaran ApresiasiSastra Lama di Sekolah Menengah Atas. In Tesis. Bandung: Pascasarjana UPI-Bandung.

Suci Prasasti. (2020). Konseling Indigenous dalam Masa New Normal. Widya Wacana:Jurnal Ilmiah, 3(1).

Sue, D. W.,\& Sue, D. (2008). Counseling The Culturally Diverse: Theory and Practice. USA: John Wiley \& Sons, Inc.

Sugiyono. (2012). Metode Penelitian Kuantitatif Kualitatif dan R\&D. Bandung: Alfabeta.

Tuwu, D. (2020). Kebijakan Pemerintah Dalam Penanganan Pandemi Covid-19. Journal Publicuho, 3(2), 267.

Wiranti, Sriatmi, A., \& Kusumastuti, W. (2020). Determinan kepatuhan masyarakat Kota Depok terhadap kebijakan pembatasan sosial berskala besar dalam pencegahan COVID-19. Jurnal Kebijakan Kesehatan Indonesia, 09(03), 117-124. 